\title{
Does social media marketing enhance impulse purchasing among female customers case study of Jordanian female shoppers
}

\author{
Mohammad Fahmi Al-Zyoud \\ Department Marketing \\ Al-Ahliyya Amman University, Jordan
}

Keywords

Social Media Marketing, Emotional Purchasing, Online Marketing

\begin{abstract}
In a report about social media presented by the Arab Social Media Influencer Summit (2015) it was mentioned that $86 \%$ of young individuals between the ages of 25-35 are involved in almost every social media website there is. Jordan registered the highest usage within the Levant are of Facebook and WhatsApp with a high usage and involvement among young citizens. The current research study aims at examining the role that social media marketing played among individuals in Jordan; precisely females and how it increased their impulsive purchasing of items through a social media platform. Through the quantitative approach, and using the questionnaire as a tool, the researcher distributed the tool on total of (400) female individuals forming a convenient sample of the study. The results of the analysis indicated that social media marketing had an influence on impulsive purchasing behavior among shoppers noting to the variable of variety seeking which presented through the social media platforms. The research however recommends a deeper investigation of how the impulsive and instant purchasing behavior was influenced by social media and the social media touched the behavior of the customer into a different scheme.
\end{abstract}

Corresponding author: Mohammad Fahmi Al-Zyoud

Email addresses for corresponding author: dr.m.alzyoud@gmail.com

First submission received: 14 $14^{\text {th }}$ February 2018

Revised submission received: $16^{\text {th }}$ April 2018

Accepted: $3^{\text {rd }}$ May 2018

\section{Introduction}

In today's marketing sphere the communication setting has been transformed by the social media. Social media has turned out to be an effective vehicle for conveying women's' rights issues to the consideration of a more extensive open, arousing activity in the city of urban areas around the globe and urging arrangement producers to venture up responsibilities regarding gender equality. It has been suggested that social media has considerably impacted marketing communication and created ties between consumers and marketers. This evolution has brought many novel opportunities and potentials within the trade and commerce and increased the accessibility of a variety of products and brands. This has impacted how consumers make purchasing decisions. Social networking marketing is one of these eminent and novel marketing innovations that has turned consumers from observers into participants. It has made it possible for consumers and brands to be connected without limitation of location, means of communication and time. It has facilitated two-way communication and changed the consumers' attitude from submissive contributors into lively manipulators and originators. The online platform offers consumers convenience as well as a large portfolio of opportunities from which consumers can select and have access to full information. It also allows consumers to access online store without restrictions and compare products of vendors internationally. Traditional business is characterized by constrained product availability, constrained closing and opening times, as well as physical location constrains; this is not the case with online shops as they are available around the clock as long as a consumer has an Internet access. The online business also accrues benefits such as absence of delivery efforts, and less social pressure. As noted by Dawson and Kim (2009) consumers tend to prefer online shopping to offline shopping because online shopping is associated with convenience. According to Dawson and Kim (2009), this convenience motivates consumers to engage in impulse buying when making purchase decisions. This trend has 
motivated researchers to give attention to online impulse buying (OIB) (Park, Kim, Funches, \& Foxx, 2012). Some researchers (Akram, Hui, Khan, Saduzai, Akram, \& Bhati, 2017; Yu, \& Bastin, 2010) have indicated that impulse buying process is controlled by emotions and that hedonics motivation influence consumers to engage in OIB behaviors. In addition, studies have suggested that impulse buying, and hedonic motivation are positively related (Zhou, Dai, \& Zhang, 2007; Hausman, 2000). It is argued that hedonic consumers tend to purchase impulsively. According to Akram et al., 2017), hedonic motivation strongly influences OIB.

Within the Jordan context, few studies have recognized the influence of social media marketing to enhance impulse purchasing. However, recent studies have mirrored the capability of social media to conquer any hindrance that frequently isolates grassroots ladies' activism from approach making forms. The blast of online networking and uncommon use by ladies of new innovations speaks to essential chances to bring sexual orientation equality and women's rights issues to the bleeding edge of both strategies making and media consideration.

With the course of time, women appeared to be more involved in the world of social media; they began using it in many different ways and approaches to express their feelings, clarify their stand points and use its tools to mingle and socialize with other people. After the appearance of the e-commerce and involving social media in the process of purchasing and marketing; consumer behavior changed and took a new perspective. Customers who were influenced by the appearance of social media marketing were also women whose purchasing behavior also took a new route reaching a state of full satisfaction and involvement in the social media purchasing (Loiseau and Nowacka, 2015).

\section{Problem Statement}

Currently, when we talk about social media, we talk about women empowerment, also, we may talk about changing women's behavior (Loiseau and Nowacka, 2015). The change in the behavior among individuals in general and women in spectacular stemmed from the fact that social media is a now a platform in which every individual has the right and the openness to perform any activity according to their mood and need. With the appearance of social media as a marketing tool the shopping and purchasing behavior of individuals changed and the idea of purchasing became more apparent and usable among them.

According to Dennis, Morgan, Wright, and Jayawardhena (2010), it was found out that marketing through social media can influence young women's shopping behavior, while Hajly (2013) indicated that the purchasing behavior changed dramatically ever since the appearance of social media websites as a platform for marketing. On the other hand, Chaiprasit (2014) noted to the fact that with the year 2020, no people would be going out to malls and markets for shopping, they all would be doing their shopping on the Internet and precisely through social media websites; the researcher added that the ease of use in addition to the trust of social media websites are among the main drivers that would change the behavior of female consumers from browsing to real purchasing intentions. Also, Nasir, Vel, and Mateen (2012) noted to the huge change that social media have had on the behavior of customers focusing on the idea that the shopping intentions of female customers has become more vivid after the entrance of social media in the world of marketing.

According to Al-Zu'bi and Almajali (2015), the obsession of shopping has become the focus of many sectors including the marketing and the psychiatrics sector in Jordan. The authors argued that women are normally more attracted to shopping sprees, and with the prevalence of the social media marketing, they have become more interested in buying items from the comfort of their own homes. In an article within a local Jordanian newspaper in 2010, it was revealed that $47 \%$ of Jordanian citizens buy at least one item/month online. The article added that the percentage of male online shoppers is almost the same as women as both have discovered the idea of buying items from their own chair without the need to move from a place to another. From that point, the researcher intention from this study is to examine the influence of social media marketing on the impulsive purchasing behavior among female consumers in Jordan. The idea of shopping through social media platforms has changed the basics of social media into a marketing media in order to attract more customers through the usage of many of social media characteristics like uploading videos, pictures not to mention the role of the word of mouth in increasing the impulse towards buying more items. 


\section{Questions, Objectives and Hypotheses}

Research Questions

Based on the problem statement, the current research seeks to answer the following questions:

R1- What is the impact of social media marketing on impulse buying among female shoppers in Jordan?

R2- What are the characteristics of online shopping that influence females to shop online and through social media websites?

R3- How can the dimensions of impulse purchasing interact with social media marketing?

Study Objectives

This study was guided by three key objectives:

To explore impulse buying behaviors among Jordanian female online shoppers and how it is influenced by social media marketing

To examine the characteristics of online shopping and how they influence females to shop online through social media websites

To examine the relationship between dimensions of impulse purchasing and social media marketing Main Hypothesis

$\mathrm{H}$ : Social media marketing has a positive influence on impulse buying among female shoppers in Jordan Sub-Hypotheses

Ha: Social media marketing has a positive influence on hedonic motivation among female shoppers in Jordan

$\mathrm{Hb}$ : Social media marketing has a positive influence on website quality among female shoppers in Jordan Hc: Social media marketing has a positive influence on trust among female shoppers in Jordan

$\mathrm{Hd}$ : Social media marketing has a positive influence on situational variable among female shoppers in Jordan

He: Social media marketing has a positive influence on variety seeking among female shoppers in Jordan

\section{The Structure of the Paper}

To cover the research objectives highlighted herein, the rest of the paper is organized as follows. First, an overview of social media marketing is given followed by an exploration of the concept of impulse buying and its dimensions influencing females to engage in online purchasing facilitated by social media marketing. Next, documented literature on the influence of Social Media Marketing on Customers' decision to purchase online (objective 1) is explored. Research objectives 2 and 3 are covered in the result section.

\section{Review of the Literature \\ Social Media Marketing}

Social media marketing is the process in which brand awareness and website traffic are increased via social media site. It also involves creating unique content to attract the attention of users and encourage them to share their contacts and share with their friends on social networking sites (Kalyanaraman, \& Sundar, 2003). These websites make use of technical applications to allow customers to "tag", "blog", "dig" and "post" content. This content is available for online users and it is spread and used by those desiring to market their products and services or brands (Xiang \& Gretzel, 2010). Most common social media sites include Digg, Google+, LinkedIn, Twitter, MySpace and Facebook (Xiang \& Gretzel, 2010). The ease of use of these social media, their reach and speed has made trendsetters in topics ranging from technology, politics, and environment to entertainment industry. The quality of these sites also makes them appealing tools for marketing brands, services and products (Xiang \& Gretzel, 2010). As such, these social media websites offer marketers the opportunity to present products and services to interested individuals and communities (Roberts \& Kraynak, 2008).

Tanuri (2010) acknowledges that marketers have started to understand the value and use of social media sites and are using them to market their products and brands as well as strategies to reach out their target customers. Sentiment research, marketing communication, customer and product management, public relation, marketing intelligence and promotions are among sub-disciplines that make use of social media marketing (Stephen \& Galak, 2009; Tanuri, 2010). According to Stephen and Galak (2009), social media platforms including online communities, online discussion forums, and blogs affect marketing 
performance. For this reason, Stephen and Galak (2009) suggests that marketers should understand their inter-relatedness and relative importance. Nielsen (2011) supports this view by indicating that marketers should reach out to these groups of highly motivated web consumers. According to Nielsen (2011), about $70 \%$ of users of social media engage in online shopping. These types of consumers seek out products and services they like through online websites and via computer screens (Nielsen, 2011). For this reason, Nielsen (2011) believes that through social media, marketers can reach their target customers and understand their tastes. Similarly, Hafele (2011) believes that social media marketing can be used by marketers to reach target customers by spreading messages to their personal contacts. According to Hafele (2011) social media marketing has increased trust in mass marketing and mass-communication and has made dissemination of information possible. Furthermore, Hafele (2011) adds that this new form of marketing and outreach has enabled marketers to develop new tools and improve businesses. It has made it possible for marketers to be effective in marketing by introducing analytic applications.

\section{Customer Behavior}

In marketing, consumer behavior refers to studying the way individual make decisions with regard to what they need, want, purchase or act in relation to service, company or product. Understanding consumer behavior is critical because it helps companies understand how customers respond to a new service/product. Three factors are known to affect consumer behavior: social, personal and psychological. Psychological factors are daily issues that are unique to the consumers' thought process. These factors can range from consumers' perception of a situation or need; the ability of the consumers to understand and learn information as well as consumers' attitude. Consumers' response to marketing message varies depending on their attitude and perceptions. For this reason, marketers are required to consider psychological factors during the creation of marketing strategies or campaigns.

Social factors are another factor that can impact on the consumer behavior. Social characteristics or influences are diverse and may include social interaction, school or work communities or person's family. These factors should be considered in consumer behavior as they influence how they respond to marketing messages and how they make the buying decisions.

Personal factors are consumers' personal characteristics. These characteristics may include unique consumer's interests, habits and opinions and how these lead consumers to making decisions. Personal factors are influenced by culture, age, background, gender, and other personal characteristics.

Impulse Buying

Technology makes buying smarter, more convenient and faster for consumers. It offers opportunities for consumers to engage in impulse buying. The steady increase in online retail sales is making companies focus on capitalizing on the convenience afforded by online shopping. They are doing this by incorporating strategies aimed at encouraging impulse buying. With increased experience in online advertising/marketing and continued evolution of technology, websites have become innovative in the way they encourage impulse purchasing with some website largely relying on impulse buying. Websites such as HauteLook.com. Ideeli.com, RueLaLa.com and others are among the websites that focus on encouraging customers' impulse purchasing. Moore (2010) sees this form of purchasing as "discoverybased shopping" and argued that it is likely to be the future of social media marketing and online shopping. These sites operate by relying on invites from an existing customer to encourage a new one to create an online account with them. This feature offers the exclusivity feeling as it makes it easy for consumers to get into these sites. A customer that create an account is allowed to access "boutiques". These are the daily offers to a customer for making a purchase. A boutique is a discounted item that is based on a specific brand. It involves multiple brands defined by underlying themes. These boutiques are only available for a limited time usually two to four days. However, there is no guarantee for the quantify product/items offered. As such, a daily e-mail is sent to a customer's informing him/her about the new boutiques in a given day and which are to be opened and sees the available items that are open for sale. All this is aimed at encouraging impulse purchasing. The website also displays items to create a sense of urgency to the consumer that encourage impulse buying.

\section{Dimensions of impulse purchasing}




\section{Hedonic Motivation}

Motivations to engage in social media marketing and other forms of online shopping include the hedonic utilitarian dimensions (Childers, Carr, Peck, \& Carson, 2001). According to Childers et al. (2001) business-to-consumer e-commerce conducted via web-shopping mechanists, provide companies with expanded opportunity to create esthetically and cognitively rich shopping experience in ways that cannot be achieved within the non-electronic shopping world. Childers et al. (2001) indicate that new media have hedonic aspect and support an interactive shopping environment. Trevino, and Webster (1992) identifies thirteen hedonic motivations for shoppers engaging in social media marketing and other forms of online marketing: motivation that are related to pleasure include role, learning trends, pleasure, self-gratification, stimulation and diversion; those related to flow namely telepresence and enjoyment; and finally, those motivations related to flow and hedonism namely control and status, and curiosity/adventure.

Social shopping involves shoppers enjoying shopping with friends, affiliating with reference groups, and communicating with other shoppers with similar shopping interests (Arnold \& Reynolds, 2003). Diversion involves a case where shoppers engage in shopping in order to diverge from routinely daily life. This way shopping is a seen as a form of recreation (Parsons, 2002). Diversion is considered a motivation because it is seen as allowing social escapism. Control or status refers to shoppers exercising control over interaction occurring via the internet and commanding respect and attention while shopping (Trevino \& Webster, 1992). Other include enjoyment; adventure/curiosity; stimulation; pleasure of bargaining; learning trends; and self-gratification (Arnold \& Reynolds, 2003; Trevino, \& Webster, 1992).

Website quality

E-commerce usually occurs on a website; in social commerce, social networking sites are used to conduct commercial activities. Studies by (Ahn, Ryu, \& Han, 2007; DeLone, \& McLean, 2004; HennigThurau, Gwinner, \& Gremler, 2002) have shown that the quality of a website impacts on e-commerce. According to Liang and Lai (2002) social networking sites provides an online platform that offers social networking services. The success of these services depends on the website quality. Similarly, DeLone and McLean (2004) suggests that the design of the social networking sites significantly impacts the social sharing shopping and social behavior of users.

Previous studies on the quality of web site as a factor influencing social media commerce have adopted two approaches. The first approach looks at the specific functions offered by the Web site and how it affects e-commerce. The second approach looks at the perception of the user towards the quality and design of the website (Liang \& Lai, 2002). An example of the functional approach to quality of a web site was by Liang and Lai (2002). Liang and Lai (2002) summarized and categorized design functions of an e-business into media richness factors, hygiene factors and design functions. Liang and Lai (2002) examined the effects of hygiene factors, media richness factors, and design factors on consumers' intention for future visits; intention to purchase, and actual purchases. On the contrary, DeLone and McLean (2004) examined the perception of users toward the design quality of a web site based on the information system success model. The success of the e-commerce was measured using information quality, system use, system quality, net benefits, user satisfaction and service quality. Service quality, information quality and system quality were identified as measures of the quality of the web site. In this context, system quality is the degree or extent to which a web site is seen to possess designed capabilities including reliability, response time and availability. Information quality denotes the extent or degree to which the web site's content is seen as complete, accurate and timely. On the other hand, service quality is the degree to which website users assess the services and support offered via the website by the service provider (Chiu, Chiu, \& Chang, 2007).

\section{Trust}

Trust refers to the belief of the user that a social media site is benevolent and honest. It is primarily the user's belief that the owner/service provider is benevolent and honest (Gustafsson, Johnson, \& Roos, 2005; Morgan, \& Hunt, 1994). Within the context of social commerce, the user is more likely to trust, show commitment and be satisfied with the services provided by the service provider if the relationship between social media site and the user is high. This also promotes confidence in the user of the social media website to share and interact with friends. This way, the user will demonstrate the 
willingness to create and maintain relationship with the owner/service provider of the social media website for purposes of ensuring he/she continues to receive good services (Garbarino, \& Johnson, 1999; Shabbir, Palihawadana, \& Thwaites, 2007). It is also argued that a well-designed social media website can promote and better meet the needs of the user for social interactions, which in turn will create a good impression in the user regarding the quality of the website, hence increasing trust and confidence in the performance of the service provider (Crosby, Evans, \& Cowles, 1990). Situational variable

Situational factors play an important role in consumers' behavior and this has been recognized and acknowledged in the marketing literature. These factors are temporal conditions that influence how buyers behave in terms of actually purchasing an additional product, actually purchasing a product, or purchasing nothing at all. These factors may include social factors, physical factors, reasons for consumers' purchase, time factors, and the mood of the buyer. The consumers' physical situation, including the design, location, and layout of a store must be considered by marketers when designing their facilities. These physical factors are under the control of the firm and are referred to as atmospherics. Consumers' social situation significantly affect what they purchase, how much they purchase of it and when they will purchase it. Certain social situations may also make a consumer less willing to purchase a product. Lastly, the consumers' time situation, namely the time of the year, the time of the day, and how much time they feel like they need to shop has an impact on what they purchase. For instance, it has been revealed that whether a consumer is an "evening person" or a "morning person" affects his or her shopping patterns (Moise, 2011). Others include consumer's mood and reason for purchase (Kozinets, 2002).

\section{Variety seeking}

Variety seeking as modelled by economists, marketers, consumer behaviorists and psychologists refers to a phenomenon involving consumers engaging in varied behaviors, including multi-brand buying or brand switching (Li, Hitt, \& Zhang, 2011). It is considered pervasive because of individuals' tendency to seek diversity when it comes to searching and experiencing goods and differentiating services and products in their life (Kahn, 1995). It may arise whenever consumers move to different shops or within purchase occasions through selecting a portfolio of services or products in different companies at one time (Simonson, 1990). Literature identifies three key factors that motivate consumers to seek variety: preference uncertainty; external situations; and satiation (Simonson, 1990; Harlam, \& Lodish, 1995). Satiation occurs when consumers seek variety when motivated by personal or internal desires for variety. External situations are situation in which consumers seek variety based on external constraints, namely multiple users, multiple needs multiple uses, multiple situations, retail environment and price promotion (Kahn, \& Raju, 1991; Menon, \& Kahn, 1995). Consumers' preference uncertainty refers to consumer seeking variety in order to have a portfolio of choice to protect interest or protect future uncertainty.

Online environment is perceived by users in a commercial way. The emergence and development of social media and other online stores have converted users into consumers (Hennig-Thurau, Gwinner, Walsh, \& Gremler, 2004). Social media has also changed how marketers and consumers communicate. Information society has an influence on product evaluation and consumer decision making processes. Social media offers a new channel via which product information is acquired through peer communication (Hennig-Tharau et al., 2004; Kozinets, 1999). The use of social media has also enabled consumers to recognize that they have influential power over via reviewing services and products used. Marketers also influence consumers through other psychological characte6ristics, such as purchase motivation, income, company/brand presence, company presentation on social media networks, workplace method of payment, demographic variables (disposal income, age and sex), type of stores (physical or online) and method of payment. Virtual communities and the internet have transformed corporations, societies and consumers with better networking, speedy access to information and enhance communication abilities (Kuruk, 2007; Sin et al., 2012).

Consumers are making use of several online platforms, notably social networks, podcasts, blogs wikis, bulletin boards to share ideas regarding products, brands, or services and to reach out to other consumers (Kozinets, 2002). The unique part of social media and its popularity is that it has revolutionized the marketing practices, including promotion and advertising (Hanna, Rohn \& Crittenden, 2011). According to Mangold and Faulds (2009) social media has greatly influenced consumer behavior 
from post-purchase behaviors to information acquisition. Supporting this view, Mersey, Davis, Malthouse, and Calder (2010), hinted that social media websites offer businesses the opportunity to interact and engage with potential customers, and establish important and strong relationships with potential customers. Moise (2011) also supports this view by indicating that social networking sites make companies attractive to consumers.

\section{Methodology}

The following section presented the methodological scheme which was followed in building the current research study, the way the raw data was collected and how the researcher will deal with the raw data in order to change it into acceptable and understandable set of results in accordance with the previously presented hypotheses and objectives.

Method

The quantitative approach was followed in the current research study. Quantitative approach was defined by Sukamolson (2006) as "The numerical representation and manipulation of observations for the purpose of describing and explaining the phenomena that those observations reflect" (p.2). However, it is worth to mention here that where the quantitative approach is used, the research must be deductive in its nature which means that the current research will be "a valid reasoning by which it is impossible to accept the premises but reject the conclusion" (Zalaghi, \& Khazaei (2016); Borrego, Douglas, \& Amelink, 2009).

\section{Research Design}

The design of the current research was positivist in its nature, it depends on the mathematical statements in order to explain and investigate a certain set of facts that have been put under the microscope in the study. The positivist design of the current research has given it a descriptive nature in which the researcher described a certain phenomenon through being detached from the society of the study based on planned and structured design leaning on questionnaire as a tool.

Tool

The current research study depended on the questionnaire as a tool of the study; the questionnaire was built by the researcher and is constituted of paragraphs that were related to each and every variable in the model of the study. The used scale in the current research study was Liker 5 scale on which the answers of the sample of the study were based on (strongly agree 5 - agree 4 - neutral 3 disagree 2 - strongly disagree 1 ).

Populations and Sample

The population of the study consisted of female shoppers and customers within the Jordanian markets in general which consisted of millions of individuals; given the fact that the population is indefinite and consisted of a large number of individuals the research depended on the sample size calculator as shown.

Based on that, a convenient sample of study was set to be initially (550) female individual from different shopping centers, malls, commercial complexes and markets. The total sample which responded to the questionnaire reached in its

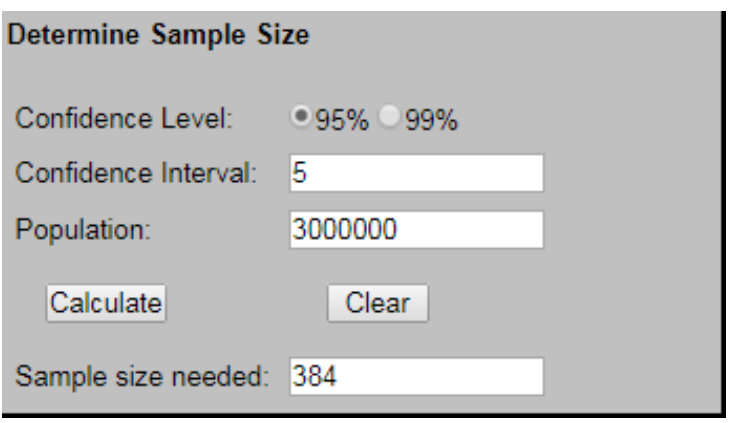
final version to (400) respondent which means that the response rate was $72.7 \%$ which is a statistically acceptable response rate.

Model of the Study 
\begin{tabular}{|l|l|}
\hline Independent Variable & Independent Variable \\
\hline
\end{tabular}

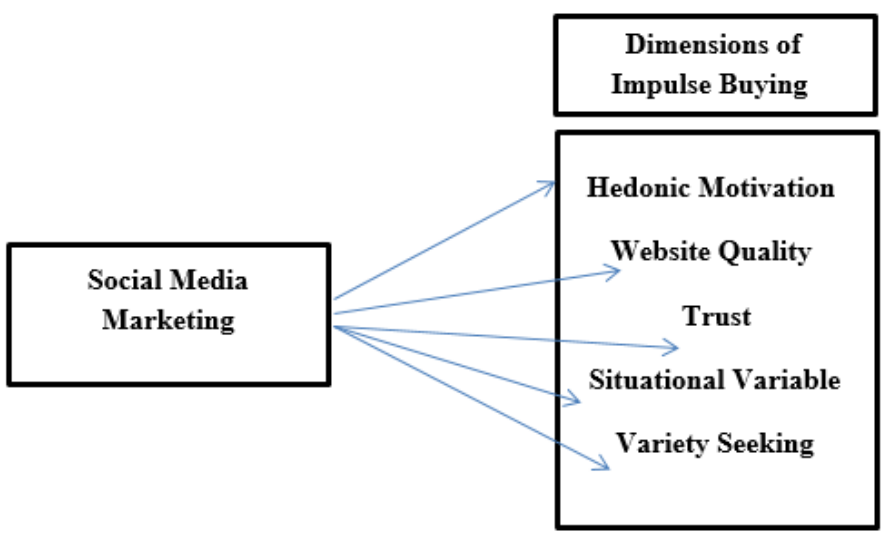

\section{Results}

The current section presents the demographic analysis of the sample of the study according to the analysis. The demographic variables consisted of (Age, social status, and income).

\section{Demographic}

The current section presents the demographic analysis of the sample of the study according to the analysis. The demographic variables consisted of (Age, Experience, and Education).

Age

According to table (1), the analysis indicates that $50.8 \%$ of the sample was females within the age range of 24-29 years which indicates that women at that age are more prone to buying items online and making impulse dictions to purchase, this is attributed to the fact that women at age are mostly financially independent, they have their own job and they support themselves financially which is a good indicator of their ability to make impulse purchasing decisions; while $22.8 \%$ of females were from the age range of +36 years which also indicates that women tend to buy stuff online regardless of their age group.

Table (1): Frequency and Percentage of Sample characteristics according to Age

\begin{tabular}{|c|l|l|l|l|l|}
\hline \multicolumn{2}{|c|}{} & Frequency & Percent & Valid Percent & Cumulative Percent \\
\hline Valid & $18-23$ & 69 & 17.3 & 17.3 & 17.3 \\
\cline { 2 - 6 } & $24-29$ & 203 & 50.8 & 50.8 & 68.0 \\
\cline { 2 - 6 } & $30-35$ & 37 & 9.3 & 9.3 & 77.3 \\
\cline { 2 - 6 } & +36 & 91 & 22.8 & 22.8 & 100.0 \\
\cline { 2 - 6 } & Total & 400 & 100.0 & 100.0 & \\
\hline
\end{tabular}

\section{Social Status}

Table (2) refers to the individuals' social status, according to the analysis, $43.3 \%$ of the sample was single women with a frequency of 173 individuals; followed but women who were married with a percentage of $23.8 \%$ and a frequency of 95 individuals and in the $3^{\text {rd }}$ rank appeared women who were separated with a percentage of $22 \%$. The results indicated that single women have more control over their purchasing decision as they are financially independent and have the ability to make impulse purchasing decisions given that they might be out of the familial responsibilities zone and might be freer in making those decisions. 
Table (2): Frequency and Percentage of Sample characteristics according to social status

\begin{tabular}{|l|l|l|l|l|l|}
\hline \multicolumn{2}{|c|}{} & Frequency & Percent & Valid Percent & Cumulative Percent \\
\hline Valid & Married & 95 & 23.8 & 23.8 & 23.8 \\
\cline { 2 - 6 } & Single & 173 & 43.3 & 43.3 & 67.0 \\
\cline { 2 - 6 } & Divorced & 44 & 11.0 & 11.0 & 78.0 \\
\cline { 2 - 6 } & Separated & 88 & 22.0 & 22.0 & 100.0 \\
\cline { 2 - 6 } & Total & 400 & 100.0 & 100.0 & \\
\hline
\end{tabular}

Income

Table (3) presents the analysis of the individuals' characteristics in reference to the income variable. The results indicated that $38.8 \%$ of the respondents enjoyed an income range of $+\$ 1400$ followed by women who had an income range of $\$ 800-1000$ with a percentage of $38.5 \%$. This also indicates that the more women get income the more they are able to make impulse buying decisions.

Table (3): Frequency and Percentage of Sample characteristics according to Experience

\begin{tabular}{|l|l|l|l|l|l|}
\hline \multicolumn{2}{|c|}{} & Frequency & Percent & Valid Percent & Cumulative Percent \\
\hline \multirow{8}{*}{ Valid } & $\$ 500-700$ & 28 & 7.0 & 7.0 & 7.0 \\
\cline { 2 - 6 } & $\$ 800-1000$ & 154 & 38.5 & 38.5 & 45.5 \\
\cline { 2 - 6 } & $\$ 1100-1300$ & 63 & 15.8 & 15.8 & 61.3 \\
\cline { 2 - 6 } & $+\$ 1400$ & 155 & 38.8 & 38.8 & 100.0 \\
\cline { 2 - 6 } & Total & 400 & 100.0 & 100.0 & \\
\hline
\end{tabular}

\section{Variable Analysis}

Research Objective 2: Characteristics of online shopping that influence females to shop online and through social media websites

As can be seen in table 4, characteristics of online shopping that influence females to shop online and via social media are hedonic, website quality, trust, situational variables, and variety seeking. It can be seen that there is a positive attitude from participants towards the relevant questions. This appeared through the mean of the paragraphs which scored higher than 3.00 referring to the paragraph as a good indicator. The most influential paragraph appeared to be the 10th paragraph articulated "The ease of use in the website encourages women to shop more" with a mean of (4.5700). This means that females are mostly influenced by the ease of use of the purchasing process which makes them able to make the purchasing decision instantly according to the process of buying and the degree of simplicity that this process is based on. However, the least influential paragraph appeared to be the 19th articulated "The brand of the item changes the behavior of female customers into impulse purchasing" with a mean of (3.5800) this paragraph indicates the fact that women to a certain degree are influenced by the brand making to have instant and impulse buying decisions. This emphasize the idea that those females who are known to make impulse buying decisions enjoy less level of brand loyalty.

Table (4): Descriptive Statistics

\begin{tabular}{|l|l|l|l|l|l|l|l|}
\hline & $\mathrm{N}$ & Minimum & Maximum & Mean & Std. Deviation \\
\hline Social media marketing & 400 & 1.00 & 5.00 & 4.3600 & .97611 \\
\hline $\begin{array}{l}\text { Women use social media as a source of } \\
\text { information }\end{array}$ & 400 & 2.00 & 5.00 & 4.3900 & .91652 \\
\hline $\begin{array}{l}\text { Social media managed to empower women over } \\
\text { the years }\end{array}$ & 400 & 2.00 & 5.00 & 4.2850 & 1.07548 \\
\hline $\begin{array}{l}\text { Women find social media attractive and easy to } \\
\text { use }\end{array}$ & 400 & 2.00 & 5.00 & 4.3450 & .98661 \\
\hline $\begin{array}{l}\text { Most women spend their free time browsing } \\
\text { social media websites }\end{array}$ & 400 & 2.00 & 5.00 & 4.4025 & .88739 \\
\hline $\begin{array}{l}\text { Women are attracted to the concept of purchasing } \\
\text { through social media }\end{array}$ & & & & \\
\hline
\end{tabular}

www.jbrmr.com A Journal of the Academy of Business and Retail Management (ABRM) 


\begin{tabular}{|c|c|c|c|c|c|}
\hline \multicolumn{6}{|l|}{ Dimensions of Impulse Buying } \\
\hline \multicolumn{6}{|l|}{ Hedonic } \\
\hline $\begin{array}{l}\text { Purchasing at the comfort of own home brings } \\
\text { pleasurable feelings to women }\end{array}$ & 400 & 2.00 & 5.00 & 4.4275 & .90098 \\
\hline $\begin{array}{l}\text { Delivery of items through social media attracts } \\
\text { women }\end{array}$ & 400 & 2.00 & 5.00 & 4.4525 & .83034 \\
\hline $\begin{array}{l}\text { Women enjoys shopping for personal items over } \\
\text { social media }\end{array}$ & 400 & 2.00 & 5.00 & 4.4600 & .85746 \\
\hline $\begin{array}{l}\text { Shopping through social media increase women's' } \\
\text { feelings of satisfaction }\end{array}$ & 400 & 2.00 & 5.00 & 4.4725 & .87244 \\
\hline \multicolumn{6}{|l|}{ Website quality } \\
\hline $\begin{array}{l}\text { The ease of use in the website encourages women } \\
\text { to shop more }\end{array}$ & 400 & 2.00 & 5.00 & 4.5700 & .74598 \\
\hline $\begin{array}{l}\text { The way the website designed increase the } \\
\text { chances of more customers }\end{array}$ & 400 & 2.00 & 5.00 & 4.4750 & .83133 \\
\hline $\begin{array}{l}\text { Colors, designs, themes and platform influence } \\
\text { women to shop more }\end{array}$ & 400 & 2.00 & 5.00 & 4.4825 & .83752 \\
\hline $\begin{array}{l}\text { Instructions and technical support of the website } \\
\text { increase the women's impulse purchasing }\end{array}$ & 400 & 3.00 & 5.00 & 4.4350 & .81697 \\
\hline \multicolumn{6}{|l|}{ Trust } \\
\hline $\begin{array}{llll}\begin{array}{l}\text { Secured payments encourages women to } \\
\text { purchase }\end{array} & & \\
\end{array}$ & 400 & 2.00 & 5.00 & 4.5000 & .80412 \\
\hline $\begin{array}{l}\text { Cash on delivery encourages women to purchase } \\
\text { more }\end{array}$ & 400 & 2.00 & 5.00 & 4.3975 & .90085 \\
\hline $\begin{array}{l}\text { Sales and discounts encourage women to buy } \\
\text { more }\end{array}$ & 400 & 2.00 & 5.00 & 4.3975 & .88400 \\
\hline Return encourages women to buy more & 400 & 2.00 & 5.00 & 3.9175 & 1.03362 \\
\hline \multicolumn{6}{|l|}{ Situational variable } \\
\hline $\begin{array}{l}\text { Sales and discounts encourage women to buy } \\
\text { items even if they don't need them }\end{array}$ & 400 & 2.00 & 5.00 & 3.8700 & 1.10958 \\
\hline $\begin{array}{l}\text { The brand of the item changes the behavior of } \\
\text { female customers into impulse purchasing }\end{array}$ & 400 & 1.00 & 5.00 & 3.5800 & 1.44180 \\
\hline $\begin{array}{l}\text { Easy delivery and support increase the impulse } \\
\text { purchasing }\end{array}$ & 400 & 2.00 & 5.00 & 3.6600 & 1.29173 \\
\hline $\begin{array}{l}\text { Comments and reviews on social media } \\
\text { marketing support impulse decision of } \\
\text { purchasing among women }\end{array}$ & 400 & 2.00 & 5.00 & 4.0675 & 1.06102 \\
\hline \multicolumn{6}{|l|}{ Variety seeking } \\
\hline $\begin{array}{l}\text { Most social media websites provide women with } \\
\text { insights much more than any other websites }\end{array}$ & 400 & 2.00 & 5.00 & 3.9425 & 1.17799 \\
\hline $\begin{array}{l}\text { Marketing for more than one brand increase } \\
\text { impulse purchasing among women }\end{array}$ & 400 & 2.00 & 5.00 & 4.1275 & .98166 \\
\hline $\begin{array}{l}\text { Variety seeking-based shopping means less brand } \\
\text { loyalty }\end{array}$ & 400 & 2.00 & 5.00 & 4.1025 & 1.03182 \\
\hline Women tend to have low brand loyalty & 400 & 2.00 & 5.00 & 3.9825 & 1.15348 \\
\hline Valid N (listwise) & 400 & & & & \\
\hline
\end{tabular}

\section{Reliability Test:}

A reliability test was carried out using Cronbach's' alpha, the result showed a value of (0.957) for all items, in addition the alpha for each variable is greater than accepted percent 0.60 , which is a reasonable value indicating the tool consistency and suitability for use in the study. 


\begin{tabular}{|l|l|l|l|l|l|}
\hline \multicolumn{1}{|l|}{ Table (5): Descriptive Statistics } \\
\hline & $\mathrm{N}$ & Minimum & Maximum & Mean & Std. Deviation \\
\hline Hedonic & 400 & 2.25 & 5.00 & 4.3450 & .94427 \\
\hline Website & 400 & 2.50 & 5.00 & 4.4356 & .82759 \\
\hline Trust & 400 & 2.50 & 5.00 & 4.5000 & .76806 \\
\hline Situational & 400 & 2.50 & 5.00 & 4.4325 & .81504 \\
\hline Variety & 400 & 2.25 & 5.00 & 3.7569 & 1.16488 \\
\hline Impulse Buying & 400 & 2.60 & 5.00 & 4.2940 & .78395 \\
\hline social & 400 & 2.20 & 5.00 & 4.0445 & 1.04463 \\
\hline Valid N (listwise) & 400 & & & & \\
\hline
\end{tabular}

Examining the above table (5), it can be seen that there is a positive attitude from participants towards the dimensions of impulse buying. This appeared through the mean of the paragraphs which scored higher than 3.00 referring to the paragraph as a good indicator. However, according to the table, the most influential factor appeared to be trust as it scored the highest mean (4.5000) referring to the influence of trust in encouraging women to make instant and impulse buying decisions.

Research Objective 1: Influence of Social Media Marketing on Customers' decision to purchase online Research Objective 3: The relationship between dimensions of impulse purchasing and social media marketing. The current sections present the results of testing the hypotheses of the study, bearing in mind that the current study was based on one main hypothesis and four sub-hypotheses to build the assertions, which the researcher is trying to support.

$\mathrm{H}$ : Social media marketing has a positive influence on impulse buying among female shoppers in Jordan

\begin{tabular}{|l|l|l|l|l|}
\hline \multicolumn{5}{|c|}{ Table (6): Model Summary } \\
\hline Model & $\mathrm{R}$ & R Square & Adjusted R Square & Std. Error of the Estimate \\
\hline 1 & $.691^{\mathrm{a}}$ & .478 & .476 & .56723 \\
\hline
\end{tabular}

a. Predictors: (Constant), social

\begin{tabular}{|l|l|l|l|l|l|l|}
\hline \multicolumn{6}{|l|}{ Table (7): ANOVA } \\
\hline \multicolumn{2}{|l|}{ Model } & Sum of Squares & df & Mean Square & F & Sig. \\
\hline \multirow{3}{*}{1} & Regression & 117.157 & 1 & 117.157 & 364.121 & $.000^{\mathrm{b}}$ \\
\cline { 2 - 7 } & Residual & 128.058 & 398 & .322 & & \\
\cline { 2 - 7 } & Total & 245.216 & 399 & & & \\
\hline
\end{tabular}

a. Dependent Variable: dep

b. Predictors: (Constant), social

\begin{tabular}{|l|l|l|l|l|l|l|}
\hline \multicolumn{2}{|l|}{ Table (8): Coefficientsa } \\
\hline \multicolumn{2}{|l|}{ Model } & Unstandardized Coefficients & Standardized Coefficients & t & Sig. \\
\cline { 3 - 8 } \multicolumn{2}{|l|}{} & B & Std. Error & Beta & & \\
\hline \multirow{2}{*}{1} & (Constant) & 2.196 & .114 & & 19.341 & .000 \\
\cline { 2 - 7 } & social & .519 & .027 & .691 & 19.082 & .000 \\
\hline
\end{tabular}

a. Dependent Variable: dep

Linear regression was used to test this hypothesis; it was found that $R(0.691)$ is the correlation of the independent variable and the dependent variable. Also, it was found that the F value of (364.121) is significant at (0.05) level. Thus, there is a statistically significant of the influence of social media on impulse buying behavior among female shoppers in Jordan.

Ha: Social media marketing has a positive influence on Hedonic Motivation among female shoppers in Jordan

\begin{tabular}{|l|l|l|l|l|}
\hline \multicolumn{5}{|l|}{ Table (9): Model Summary } \\
\hline Model & R & R Square & Adjusted R Square & Std. Error of the Estimate \\
\hline 1 & $.529 \mathrm{a}$ & .280 & .278 & .80217 \\
\hline
\end{tabular}

a. Predictors: (Constant), social 


\begin{tabular}{|l|l|l|l|l|l|l|}
\hline \multicolumn{7}{|l|}{ Table (10): ANOVA $\mathrm{a}$} \\
\hline \multicolumn{2}{|l|}{ Model } & Sum of Squares & df & Mean Square & F & Sig. \\
\hline \multirow{3}{*}{1} & Regression & 99.660 & 1 & 99.660 & 154.876 & $.000^{\mathrm{b}}$ \\
\cline { 2 - 7 } & Residual & 256.105 & 398 & .643 & & \\
\cline { 2 - 7 } & Total & 355.765 & 399 & & & \\
\hline
\end{tabular}

a. Dependent Variable: Hedonic

b. Predictors: (Constant), social

\begin{tabular}{|c|c|c|c|c|c|c|}
\hline \multicolumn{7}{|c|}{ Table (11): Coefficients ${ }^{\mathrm{a}}$} \\
\hline \multirow{2}{*}{\multicolumn{2}{|c|}{ Model }} & \multicolumn{2}{|c|}{ Unstandardized Coefficients } & \multirow{2}{*}{$\begin{array}{l}\text { Standardized Coefficients } \\
\text { Beta }\end{array}$} & \multirow[t]{2}{*}{$\mathrm{t}$} & \multirow[t]{2}{*}{ Sig. } \\
\hline & & B & Std. Error & & & \\
\hline \multirow[t]{2}{*}{1} & (Constant) & 2.410 & .161 & & 15.009 & .000 \\
\hline & social & .478 & .038 & .529 & 12.445 & .000 \\
\hline
\end{tabular}

a. Dependent Variable: Hedonic

Linear regression was used to test this hypothesis; it was found that $\mathrm{R}(0.529)$ is the correlation of the independent variable and the dependent variable. Also, it was found that the F value of (154.876) is significant at (0.05) level. Thus, there is a statistically significant influence of social media on the concept of hedonic motivation among female shoppers in Jordan.

$\mathrm{Hb}$ : Social media marketing has a positive influence on website quality among female shoppers in Jordan

\begin{tabular}{|l|l|l|l|l|}
\hline \multicolumn{4}{|c|}{ Table (12): Model Summary } \\
\hline Model & R & R Square & Adjusted R Square & Std. Error of the Estimate \\
\hline 1 & $.539 a$ & .291 & .289 & .69793 \\
\hline
\end{tabular}

a. Predictors: (Constant), social

\begin{tabular}{|l|l|l|l|l|l|l|}
\hline \multicolumn{6}{|l|}{ Table (13): ANOVA $\mathrm{a}$} \\
\hline \multicolumn{2}{|l|}{ Model } & Sum of Squares & df & Mean Square & F & Sig. \\
\hline \multirow{3}{*}{1} & Regression & 79.410 & 1 & 79.410 & 163.024 & $.000^{\mathrm{b}}$ \\
\cline { 2 - 7 } & Residual & 193.870 & 398 & .487 & & \\
\cline { 2 - 7 } & Total & 273.280 & 399 & & & \\
\hline
\end{tabular}

a. Dependent Variable: Website

b. Predictors: (Constant), social

\begin{tabular}{|l|l|l|l|l|l|l|}
\hline \multicolumn{2}{|l|}{ Table (14): Coefficientsa } \\
\hline \multicolumn{2}{|l|}{ Model } & Unstandardized Coefficients & Standardized Coefficients & $\mathrm{t}$ & Sig. \\
\cline { 3 - 8 } & B & Std. Error & Beta & & \\
\hline \multirow{2}{*}{1} & (Constant) & 2.708 & .140 & & 19.386 & .000 \\
\cline { 2 - 7 } & social & .427 & .033 & .539 & 12.768 & .000 \\
\hline
\end{tabular}

a. Dependent Variable: Website

Linear regression was used to test this hypothesis; it was found that $R(0.539)$ is the correlation of the independent variable and the dependent variable. Also, it is found that the F value of (163.024) is significant at (0.05) level. Thus, there is a statistically significant influence of social media on website quality among female shoppers in Jordan.

Hc: Social media marketing has a positive influence on trust among female shoppers in Jordan

\begin{tabular}{|l|l|l|l|l|}
\hline \multicolumn{4}{|l|}{ Table (15): Model Summary } \\
\hline Model & R & R Square & Adjusted R Square & Std. Error of the Estimate \\
\hline 1 & $.542^{\mathrm{a}}$ & .294 & .292 & .64621 \\
\hline
\end{tabular}

a. Predictors: (Constant), social

\begin{tabular}{|l|l|l|l|l|l|l|}
\hline \multicolumn{7}{|l|}{ Table (16): ANOVA $^{\text {a }}$} \\
\hline \multicolumn{2}{|l|}{ Model } & Sum of Squares & df & Mean Square & F & Sig. \\
\hline \multirow{2}{*}{1} & Regression & 69.176 & 1 & 69.176 & 165.656 & $.000^{\mathrm{b}}$ \\
\cline { 2 - 7 } & Residual & 166.199 & 398 & .418 & & \\
\cline { 2 - 7 } & Total & 235.375 & 399 & & & \\
\hline
\end{tabular}

a. Dependent Variable: Trust

b. Predictors: (Constant), social

www.jbrmr.com A Journal of the Academy of Business and Retail Management (ABRM) 


\begin{tabular}{|c|c|c|c|c|c|c|}
\hline \multicolumn{7}{|c|}{ Table (17): Coefficientsa } \\
\hline \multirow{2}{*}{\multicolumn{2}{|c|}{ Model }} & \multicolumn{2}{|c|}{ Unstandardized Coefficients } & \multirow{2}{*}{$\begin{array}{l}\text { Standardized Coefficients } \\
\text { Beta }\end{array}$} & \multirow[t]{2}{*}{$\mathrm{t}$} & \multirow[t]{2}{*}{ Sig. } \\
\hline & & $\mathrm{B}$ & Std. Error & & & \\
\hline \multirow[t]{2}{*}{1} & (Constant) & 2.888 & .129 & & 22.326 & .000 \\
\hline & social & .399 & .031 & .542 & 12.871 & .000 \\
\hline
\end{tabular}

\section{a. Dependent Variable: Trust}

Linear regression was used to test this hypothesis; it was found that $\mathrm{R}(0.542)$ is the correlation of the independent variable and the dependent variable. Also, it was found that the F value of (165.656) is significant at (0.05) level. Thus, there is a statistically significant influence of social media on trust among female shoppers in Jordan.

$\mathrm{Hd}$ : Social media marketing has a positive influence on situational variable among female shoppers in Jordan

\begin{tabular}{|l|l|l|l|l|}
\hline \multicolumn{5}{|l|}{ Table (18): Model Summary } \\
\hline Model & R & R Square & Adjusted R Square & Std. Error of the Estimate \\
\hline 1 & $.550 \mathrm{a}$ & .302 & .301 & .68161 \\
\hline
\end{tabular}

a. Predictors: (Constant), social

\begin{tabular}{|l|l|l|l|l|l|l|}
\hline \multicolumn{7}{|l|}{ Table (19): ANOVA } \\
\hline \multicolumn{2}{|l|}{ Model } & Sum of Squares & df & Mean Square & F & Sig. \\
\hline \multirow{2}{*}{1} & Regression & 80.143 & 1 & 80.143 & 172.499 & $.000^{\mathrm{b}}$ \\
\cline { 2 - 7 } & Residual & 184.910 & 398 & .465 & & \\
\cline { 2 - 7 } & Total & 265.053 & 399 & & & \\
\hline
\end{tabular}

a. Dependent Variable: Situational

b. Predictors: (Constant), social

\begin{tabular}{|l|l|l|l|l|l|l|}
\hline \multicolumn{2}{|l|}{ Table (20): Coefficientsa } \\
\hline \multicolumn{2}{|l|}{ Model } & Unstandardized Coefficients & Standardized Coefficients & \multirow{2}{*}{ t } & & \\
\cline { 3 - 8 } \multicolumn{2}{|l|}{} & B & Std. Error & Beta & & \\
\hline \multirow{2}{*}{1} & (Constant) & 2.697 & .136 & & 19.769 & .000 \\
\cline { 2 - 7 } & social & .429 & .033 & .550 & 13.134 & .000 \\
\hline
\end{tabular}

a. Dependent Variable: Situational

Linear regression was used to test this hypothesis; it is found that $\mathrm{R}(0.55)$ was the correlation of the independent variable and the dependent variable. Also, it was found that the F value of (172.499) is significant at (0.05) level. Thus, there is a statistically significant influence of social media on the situational variable among female shoppers in Jordan.

He: Social media marketing has a positive influence on variety seeking among female shoppers in Jordan

\begin{tabular}{|l|l|l|l|l|}
\hline \multicolumn{5}{|l|}{ Table (21): Model Summary } \\
\hline Model & R & R Square & Adjusted R Square & Std. Error of the Estimate \\
\hline 1 & $.772^{\mathrm{a}}$ & .596 & .594 & .74179 \\
\hline
\end{tabular}

a. Predictors: (Constant), social

\begin{tabular}{|l|l|l|l|l|l|l|}
\hline \multicolumn{7}{|l|}{ Table (22): ANOVA } \\
\hline \multicolumn{2}{|l|}{ Model } & Sum of Squares & df & Mean Square & F & Sig. \\
\hline \multirow{3}{*}{1} & Regression & 322.418 & 1 & 322.418 & 585.945 & $.000^{\mathrm{b}}$ \\
\cline { 2 - 7 } & Residual & 219.001 & 398 & .550 & & \\
\cline { 2 - 7 } & Total & 541.419 & 399 & & & \\
\hline
\end{tabular}

a. Dependent Variable: Variety

b. Predictors: (Constant), social

\begin{tabular}{|l|l|l|l|l|l|l|}
\hline \multicolumn{2}{|l|}{ Table (23): Coefficients } \\
\hline \multicolumn{2}{|l|}{ Model } & Unstandardized Coefficients & Standardized Coefficients & $\mathrm{t}$ & Sig. \\
\cline { 3 - 8 } & B & Std. Error & Beta & & \\
\hline \multirow{2}{*}{1} & (Constant) & .276 & .148 & & 1.862 & .063 \\
\cline { 2 - 7 } & Social & .861 & .036 & .772 & 24.206 & .000 \\
\hline
\end{tabular}

a. Dependent Variable: Variety 
Linear regression was used to test this hypothesis; it was found that $\mathrm{R}(0.772)$ was the correlation of the independent variable and the dependent variable. Also, it was found that the F value of (585.945) is significant at (0.05) level. Thus, there is a statistically significant influence of social media marketing on variety seeking among female shoppers in Jordan.

\section{Discussion}

According to the analysis of the study which was retrieved from data collection of the individuals' responses to the questionnaire; it was found out that social media marketing has a strong influence in changing the customer behavior and it supports the concept of impulse purchasing among females in Jordan. The study also found out that marketing on the internet and specifically social media has an influence over female shoppers to make sudden and instant decisions to buy an item based on the source of the ad. Meaning that, women are attracted to buying items online and use the tools that are presented through social media websites like commenting and reviewing as it gives them the chance to express their feelings, and be more aware of the item that they are buying more than being aware of the purchasing process.

The results of the study matched those results presented by (Yu and Bastin, 2010) who argued that it is not shopping that brings good feeling to the individuals, it is the idea of shopping online from the comfort of one's home that changes the mood of the purchaser into a whole different experience. Individuals enjoy the pleasurable feelings of buying online specially from the social media websites including Facebook and Instagram.

Also, Johar (2015) noted to the fact that women are more attracted to involve into online purchasing compared to men who are more into buying their items from a real life store more than online stores, the idea is attributed to the fact that women are more attracted to the concept of brands and trademarks which make them more ready to buy an item based not on its price but rather on the brand and the manufacturer. Among the results that are presented through the analysis is the influence of website design and website characteristic in encouraging women to make instant buying decisions. The results indicate that the way a website is designed and the way the ad is presented in the website plays a huge role in interfering with the customer buying behavior. On the same idea, Crafts (2007) argued a website characteristic would appear to have an imperative part in the impulsive purchasing process and energizing customers to buy as a result.

Similarly, Chen, Su and Widjaja (2016) noted to the fact that social commerce plays a huge role in attracting more customers and increase the level of impulse buying, this refers to the idea that social commerce can change and influence the behavior of the customers. One of the aspects of changing the customer behavior is the increase of the impulsive purchasing based on the different dimensions of impulsive purchasing that are influenced by the existence of social media tools and the degree of popularity of social media websites among individuals. These results align with the findings of the current study, which marked how influential social media could be on the purchasing behavior of customers.

As for the dimensions of impulsive purchasing that were used by the researcher in the current study (hedonic, website quality, trust, situational variable and variety seeing), the results indicate that all the mentioned variables played a role in increasing the level of impulsive purchasing behavior among individuals. The results also indicated that the most influential variable of all the dimensions taken by the researcher is 'variety seeking' with a value $R=.772^{a}$. The results of the current study indicate that variety seeking is apparent within the social media-based marketing that scored the highest $\mathrm{R}$ value; this aligns with the findings by Sundström, Balkow, Florhed, Tjernström, and Wadenfors (2013). This is justified by the fact that marketing through social media is somewhat supporting the idea of variety seeking as it encourages brand switching bringing plans and strategies almost to every brand. Hence, customers may find different offers for different brands. Looking at the nature of women, there appeared a tendency among women to change and try every brand there is, so it is logical to see that social media brings out the variety option increasing impulsive purchasing among women. 


\section{Conclusion}

The current study aimed at examining the influence of social media marketing on the impulsive purchasing behavior among female customers in Jordan. The researcher took into perspective some dimensions of impulsive purchasing which includes (hedonic, website quality, trust, situational variable and variety seeing). Through the quantitative approach and using the questionnaire as a tool; the researcher employed (400) female customer to form the convenient sample of the study. Through the analysis, the study indicated that social media marketing can easily increase the level of impulsive behavior in purchasing considering that the chances that are presented by social media like (commenting, reviewing, feedback and rating) can help customers in deciding whether to take the purchasing decision. This in turn was found to be influential in encouraging females to take instant and impulsive decisions to purchase a certain item. In addition to that, one of the variables (variety seeking) was found to be the most influential variable referring to the process of presenting more than one option, brand or trademark for a certain product that supports the brands switching among customers and decreases the chances of brands loyalty.

\section{Recommendations}

The finding of the present study suggests that marketers should acknowledge and respond to the increasing importance of social media sites because they influence the purchase intention of customers and influence female customers to engage in impulse buying. Accordingly, we recommend that companies should implement social media marketing by continuously monitoring consumers' concerns and adjust their online marketing strategies.

Result of this study also reveals the need for online companies in Jordan to engage online shoppers and offer them the opportunity for discussion amongst themselves via social media platforms. This would allow customers to socialize and engage in impulse buying. Online impulse buying is strongly influenced by social shopping in Jordan social commerce environment. When shoppers socialize, they purchase good from online shops without thinking.

\section{Reference}

Akram, U., Hui, P., Khan, M.K., Saduzai, S.K., Akram, Z., \& Bhati, M.H. (2017), “The plight of humanity: Online impulse shopping in China. Hum", Syst. Manag, vol. 36, pp.73-90.

Ahn, T., Ryu, S., \& Han, I. (2007), "The impact of Web quality and playfulness on user acceptance of online retailing", Information \& Management, vol. 44. No. 3, pp. 263-275.

Arab Social Media Influencers Summit (2015), “Social Media Report”, [online] TNS. Available at:

https://www.wpp.com/govtpractice/ /media/wppgov/files/arabsocialmediareport-2015.pdf [Accessed 19 Aug. 2017].

Arnold, M.J., \& Reynolds, K.E. (2003), “Hedonic shopping motivations," Journal of Retailing, vol. 79, no.2, pp. 77-95.

Barefoot, D., and J. Szabo. (2010), "Friends with benefits: A social media-marketing handbook", No Starch Press, San Francisco:

Chaiprasit, C. (2014), "Shopping on Social Networking Web Sites: Female Consumers' Intentions to Shop on Facebook in Bangkok Area", [online] Available at:

http://utcc2.utcc.ac.th/utccijbe/_uploads/InProcess/201511/SHOPPING\%20ON\%20SOCIAL\%20NETWORKING\% 20WEB\%20SITES.pdf [Accessed 19 Aug. 2017].

Chen, J., Su, B. and Widjaja, A. (2016), "Facebook C2C social commerce: A study of online impulse buying", Decision Support Systems, vol. 83, pp.57-69.

Childers, T.L., Carr, C.L., Peck, J., \& Carson, S. (2001), “Hedonic and utilitarian motivations for online retail shopping behavior", Journal of Retailing, vol. 77, no. 4, pp.511-535

Chiu, C.-M., Chiu, C.-S., \& Chang, H.C. (2007), "Examining the integrated influence of fairness and quality on learners' satisfaction and Web-based learning continuance intention", Information Systems Journal, vo. 17, no. 3, pp.271-287.

Crafts, C. (2012), "Impulse Buying on the Internet", Master of Science, Louisiana State University.

Crosby, L.A., Evans, K.R., \& Cowles, D. (1990), “Relationship quality in services selling: An interpersonal influence perspective", Journal of Marketing, vol. 54, no.3, pp.68-81.

Dawson, S., \& Kim, M. (2009), “External and internal trigger cues of impulse buying online. Direct Mark”, Int. J, vol. 3, pp.20-34.

DeLone, W.H., \& McLean, E.R. (2004), “Measuring e-commerce success: Applying the DeLone \& McLean information systems success model", International Journal of Electronic Commerce, vol.9, no. 1, pp.31-47.

www.jbrmr.com A Journal of the Academy of Business and Retail Management (ABRM) 
Dennis, C., Morgan, A., Wright, L. and Jayawardhena, C. (2010), “The Influences of Social e-Shopping in Enhancing Young Women's Online Shopping Behaviour", Journal of Customer Behaviour, vol. 9, no.2, pp.151-174.

Garbarino, E., \& Johnson, M.S. (1999), "The different roles of satisfaction, trust, and commitment in customer relationships". Journal of Marketing, vol. 63, no. 2, pp.70-87.

Gustafsson, A., Johnson, M.D., \& Roos, I. (2005), “The effects of customer satisfaction, relationship commitment dimensions, and triggers on customer retention", Journal of Marketing, vol. 69, no. 4, 210-218.

Hafele, N. (2011), "Social Media Marketing: Interaction, Trends \& Analytics”, ICT 511 Fall, vol. 51, no.3, pp. 1-6

Hajli, N. (2017), "A study of the impact of social media on consumers", International Journal of Market Research, vol. 56, no.3.

Hanna, R., Rohm, A. \& Crittenden, V., (2011), "We're all connected: The power of the social media ecosystem", Business Horizons, vol. 54, no.3, pp. 265-273.

Harlam, B.A., \& Lodish, L.M. (1995), "Modeling Consumers' Choices of Multiple Items", Journal of Marketing Research, vol. 32, no.4, pp. 404-418.

Hennig-Thurau T., Gwinner K., Walsh G. \& Gremler D., (2004), “Electronic Word-of-Mouth Via Consumer Opinion Platforms: What Motivates Consumers to Articulate Themselves on the Internet?" Journal of Interactive Marketing, vol. 18, no.3, pp. 38-52.

Hennig-Thurau, T., Gwinner, K.P., \& Gremler, D.D. (2002), “Understanding relationship marketing outcomes: An integration of relational benefits and relationship quality", Journal of Service Research, vol. 4, no. 3, pp.230-247.

Hausman, A. (2000), "A multi-method investigation of consumer motivations in impulse buying behavior", J. Consum. Mark, vol. 17, pp.403-417.

Jeffrey, S.A., and Hodge, R., (2007), "Factors influencing impulse buying during an online purchase", Electronic Commerce Research, vol. 7, no.3, pp.367-379.

Johar, J. (2015), “The Influence of Situational Variables on Consumer Choice Behavior, And Its Impact on Marketing Strategy'. Proceedings of the 1984 Academy of Marketing Science (AMS) Annual Conference, pp.471-471.

Kahn, B.E. (1995), "Consumer Variety-Seeking among Goods and Services: An Integrative Review", Journal of Retailing and Consumer Services, vol. 2, no.3, pp.139-148.

Kahn, B.E., \& Raju, J.S. (1991), "Effects of Price Promotions on Variety-Seeking and Reinforcement Behavior", Marketing Science, vol. 10, no.4, pp.316-337.

Kalyanaraman, S. \& Sundar, S.S. (2003), “The psychological appeal of personalized online content: an experimental investigation of customized web portals", Paper presented at the meeting of the International Communication Association, San diego, May.

Kozinets, R. V., (1999), E-tribalized Marketing? The Strategic Implications of Virtual Communities of Consumption, European Management Journal, vol.17, no.3, pp.252-64.

Kozinets, R.V., Valck K., Wojnicki A.C., \& Wilner S. J.S., (2010), “Networked Narratives: Understanding Word-ofMouth Marketing in Online Communities", Journal of Marketing, vol. 74, no.2, pp.71-89.

Kuruk K., (2007), “An analysis of consumer power on the Internet” Technovation vol.27, no.1-2, pp.47-56.

Li, X., Hitt, L.M., \& Zhang, Z.J. (2011), "Product Reviews and Competition in Markets for Repeat Purchase Products", Journal of Management Information Systems, vol. 27, no.4, pp.9-41.

Liang, T.P., \& Lai, H.J. (2002), "Effect of store design on consumer purchase: An empirical study of on-line bookstores", Information $\mathcal{E}$ Management, 39,

Mangold, G., and Faulds D., (2009), "Social media: The new hybrid element of the promotion mix", Business Horizons, vol.52, pp.357-365.

Menon, S., \& Kahn, B.E. (1995), "The Impact of Context on Variety Seeking in Product Choices", The Journal of Consumer Research, vol. 22, no.3, pp.285-295.

Mersey, R., Davis, Malthouse E. \& Calder B., (2010), “Engagement with Media”, Journal of Media Business Studies, vol. 7, no.2, pp.39 -56.

Moise D., (2011), "Marketing strategies - strategic context specific to communication in events marketing", Romanian Journal of Marketing, Ed. Rosetti Educational, vol. 1, no.26.

Morgan, R.M., \& Hunt, S.D. (1994), "The commitment-trust theory of relationship marketing”, Journal of Marketing, vol. 58, no.3, pp. 20-38.

Nasir, S., Vel, P., and Mateen, H. (2012), Social media and buying behavior of women in Pakistan towards the purchase of textile garments.

Nielsen. (2011), "State of the media: the social media report", Nielsen Company. Retrieved from

Novak, T.P., Hoffman, D.L., \& Yung, Y.F. (2000), "Measuring the customer experience in online environment: a structural modeling approach," Marketing Science vol. 19, no.1, pp.22-44.

Parsons, A.G. (2002), “Non-functional motives for online shoppers: why we click," The Journal of Consumer Marketing vol. 19, no.5, pp.380-392. 
Park, E.J., Kim, E.Y., Funches, V.M., \& Foxx, W. (2012), “Apparel product attributes, web browsing, and e-impulse buying on shopping websites", J. Bus. Res, vol. 65, pp. 1583-1589.

Shabbir, H., Palihawadana, D., \& Thwaites, D. (2007), "Determining the antecedents and consequences of donorperceived relationship quality - A dimensional qualitative research approach", Psychology E Marketing, vol.24, no.3, pp.271-293.

Simonson, I. (1990), "The Effect of Purchase Quantity and Timing on Variety-Seeking Behavior", Journal of Marketing Research vol. 27, no.2, pp.150-162.

Sin, S., Nor, K.M., \& Al-Agaga A. M. (2012), “Factors Affecting Malaysian young consumers' online purchase intention in social media websites", Procedia - Social and Behavioral Sciences, vol. 40, Pp.326-333.

Stephen, A. T., and J. Galak. (2009), “The complementary roles of traditional and social media in driving marketing performance". Retrieved from http://bear.warrington.ufl.edu/weitz/mar7786/Articles/social\%20 and\%20tradiitonal\%20media.pdf? http:/ / blog.nielsen.com/nielsenwire/social/

Sundström,1, M., Balkow, J., Florhed, F., Tjernström, M. and Wadenfors, P. (2013), “Impulsive Buying Behavior”, The Role of Feelings When Shopping for Online Fashion. EAERCD, vol. 3, no.5.

Tanuri, I. (2010), "A literature review: Role of social media in contemporary marketing". Retrieved from http:/ /agroovyweb.com/2010/03/11/university-of-chicago-and-my-literature- review-role-of-social-mediain-contemporary-marketing/

Trevino, L. K. \& Webster, J. (1992), "Flow in computer-mediated communication: electronic mail and voice mail evaluation and impacts," Communication Research, voll. 19, no. 5, pp.539-573.

Trevino, L. K., \& Webster, J. (1992), “Flow in computer-mediated communication: electronic mail and voice mail evaluation and impacts," Communication Research, vol. 19, no.5, pp.539-573.

Williams, T., and Williams R., (2008), “Adopting social media: Are we leaders, managers or followers?" Communication World, vol. 25, no.4, pp. 34-37.

Xiang, Z., and U. Gretzel. (2010), "Role of social media in online travel information search", Tourism Management vol. 31, pp.179-188.

Yu, C. and Bastin, M. (2010), “Hedonic shopping value and impulse buying behavior in transitional economies: A symbiosis in the Mainland China marketplace", Journal of Brand Management, vol.18, no.2, pp.105-114.

Zhou, L.; Dai, L., \& Zhang, D. (2007), "Online shopping acceptance model: A critical survey of consumer factors in online shopping", J. Electron. Commer. Res, vo. 8, pp.41-62. 